\title{
Migration, Wages and Agriculture: Empirical Evidence and Policy Implications
}

\author{
Mahendra P. Agasty, Dr. Rabi N. Patra \\ Assistant Professor of Economics, Silicon Institute of Technology, Bhubaneswar-751024 \\ Deputy Director, Gopabandhu Academy of Administration, Bhubaneswar-751023
}

\begin{abstract}
How does labour out migration impact on labour supply, wage rate, size and composition of costs, productivity, production, cropping pattern and land use in agriculture? Putting in context the theoretical and empirical perspectives and using household survey data, this paper attempts to explain some of these issues. The results are more in agreement with market theory of wages than with the labour surplus and dual economy models. They indicate that migration has a strong bearing on agriculture and the labour-wage problems are likely to be more serious in future. Diversification favouring more land-intensive agricultural production, promoting location and small farm size specific technological innovations, a community approach to farm labour and a pragmatic redesigning and implementation of MNREGA and food security programmes can be helpful.

Key Words: Migration, Agriculture, Minimum Wages Act, Odisha, MNREGA

JEL Classification: J61, R 23, Q12, Q15
\end{abstract}

\subsection{Backdrop}

\section{Introduction}

During the last three decades or so the national and state economies in India, including Odisha, have been witnessing pervasive changes in the occupational pattern of workers and labour markets. These are manifested in movement of labour geographically, from the rural to the urban areas, and occupationally, from the agricultural to the non-agricultural sectors and increasing participation of women in paid work. Increasing urbanization and expansion of urban jobs, diversification of economic activities in the rural areas itself favouring non-farm and informal sectors (petty business, construction works, small transport operations etc.), and the implementation of the Mahatma Gandhi National Rural Employment Guarantee Act (MNGEGA) and special food security programmes for the below poverty line (BPL) families have contributed to the observed structural shifts in the work patterns and people's participation in the labour markets. Rural workers, by and large, are exhibiting exemplary dynamism, getting increasingly disinterested in agricultural work and are moving out of agriculture and rural areas. Since agriculture involves highly labour- intensive operations and workers are withdrawing from farm activities, the agricultural sector is facing acute shortage of labour and rising wages and costs- a dual loss indeed. In some areas the wage rise has been large enough to render the minimum wage law meaningless and astonishingly has not been able to check the rural and agricultural exodus.

\subsection{Review of literature}

The impacts of migration, MNREGA and food security programmes (for the BPL families) on sectoral labour flows, labour force participation, wage rate and agriculture, though immensely significant for agricultural development policies, have surprisingly remained a less researched area as yet. Available literatures contain a few studies covering some aspects of the issues in the agricultural labour market in India and elsewhere. A short review of these studies is presented here to indentify the research gaps with an attempt to address some of them. Most of the works (Rozelle et al, 1999; Ohajianya, 2005; Mc Carthy et al, 2006; Parganiha et al, 2009; Brauw, 2010; Miluka, et al, 2010; Prabakar et al, 2011; Brennan et al, 2012; Ofuoku and Chukwuji, 2012) found that rural out migration reduces labour supply to agriculture. But the results of these studies lack unanimity in so far as the effect of lower labour supply on agriculture is concerned. While Brennan et al (2012) observed the impact of rural-urban migration on farm output to be very minimal in the case of Vietnamese agriculture; using 2002 and 2003 Living Standard Measurement Studies on Albania, Mc Carthy et al (2006) found evidence of increase in agricultural income despite migration-led reduction in the allocation of labour to crop production. On the basis of the Vietnam Living Standard Survey data for 1992-93 and 1997-98, Brauw (2010) established that faced with reduced labour supply to agriculture, the migrant households changed the crop-mix from a relatively more labour-intensive rice crop to comparatively more land-intensive non-rice crops. The study by Rozelle et al (1999) relating to north-east China indicated that the remittance effect more than offset the lost labour effect resulting in higher crop yields for the migrant households in comparison to the non-migrant households. On the 
contrary, Ohajianya's (2005) study in Imo state of Nigeria revealed that labour migration out of agriculture impacted negatively on farm output. From their investigation in Cuddalore district of Tamil Nadu, Prabakar et al (2011) found that acute shortage of farm labour following migration has adversely affected productivity levels of all crops. Similarly, Ofuoku and Chukwuji's (2012) research in respect of Nigeria Delta revealed the negative impact of rural-urban migration induced reduced labour supply on harvesting and farm revenue in the case of plantation agriculture.

An anatomical analysis of the above review reveals that existing research works on the theme are time and area specific studies. They have captured only a limited aspect of the issues to the neglect of the impact of changes in the labour market on wages, size and structure of farm costs, productivity and output in agriculture. This paper is a modest attempt to fill the aforestated gaps in research with the help of an in-depth study in the state of Odisha, India.

\subsection{Objectives}

The specific objective of this paper is to explore the possible implications and examine the impact of rural-urban labour migration, MNREGA and food security programmes on labour supply, wage rate, cost of production and productivity, output and land use pattern in agriculture. To address this objective the following research issues have been outlined.

1. How are labour supply and wage rate determined in agriculture?

2. Does migration reduce labour supply to agriculture and raise farm wages?

3. Is the apprehension about labour scarcity and wage rise in agriculture due to minimum wage laws and MNREGA correct and valid?

4. How does labour shortage and wage increase impact on labour use, mechanisation size and structure of costs, productivity, production and land utilization pattern in agriculture?

\subsection{Data and Methods}

The paper analyses secondary data collected from various published sources. It also uses primary data collected by applying a four-stage random sampling procedure. Selection of the district, blocks, villages and households constitute the four stages. 100 households having sent 139 working male migrants, 50 households with returned migrants and 150 non-migrant households from six villages, two each from three blocks of Kendrapara district, have been considered for in-depth investigation. Data have been collected by canvassing a pre-tested schedule in person among the respondents for three reference years 2002, 2007 and 2012. Care has been taken to elicit reasonably correct information from them by adopting cross questioning and peer group discussion procedures. Simple statistical tools have been employed to analyse the data and draw conclusions therefrom.

\subsection{Structure of the paper}

The paper is organized in four sections. The working of the labour market and wage formation in agriculture have been analysed in the following section with insights from economic theory and public policy. Empirical findings have been presented in section-III. Section-IV concludes the paper with some policy implications.

\section{The Labour Market and Wage Formation in Agricultures: Theories, Myths and Reality}

For obvious reasons working of the labour market and wage formation are central to any discussion concerning agriculture. Both are complex issues as well because they are conditioned by socio-cultural and institutional forces, mobility of labour, non-farm work opportunities, relative wages, workers' attitude and government policies. Above all, they also impact significantly on the well-being of the agriculture dependent households.

\subsection{Wage Theories and their Relevance to Agriculture}

Economic theory provides four basic principles which are relevant to wage formation in agriculture. The first is the subsistence theory which views the wage rate as the natural price of labour that is just necessary for the subsistence of workers and to perpetuate their race without increase or diminution (Ricardo, 1815; Sraffa, 1960). The second is the marginal productivity theory which postulates a wage rate equal to the marginal product of labour (Clark, 1899; Hicks, 1932: Marshall, 1890). The third, the nutritionally based efficiency wage hypothesis, links wages to efficiency of labour through consumption (Liebenstein, 1957; Majumdar, 1959; Mirrlees, 1975; Rodgers, 1975; Stiglitz, 1976). Finally, the demand and supply/ market/ modern theory considers wages as the economic price of labour being determined by the demand and supply forces and hence by the relative bargaining power of the workers and employers. 
In low income economies agriculture is conventionally identified with a subsistence sector characterized by zero or negligible opportunity cost of labour, overcrowding and close-to-zero marginal product of labour, interlinked factor markets and tied labour, and an abysmally low and stable equilibrium wage rate. Subsistence agriculture, surplus labour and low wage rate are the cornerstones of the traditional dual economy growth models (Lweis, 1954; Ranis-Fei, 1964) and prominent migration theories (Todaro, 1969; Harris-Todaro, 1970). An important implication of these theories and the dual economy models is that economic growth, structural transformation and rural out migration can lead to a labour shortage and raise wages in agriculture.

\subsection{Government Intervention in the Labour Market and Minimum Wage Laws}

Historically, subsistence and low farm wages are accepted as the outcome of surplus rural labour. But, contemporarily they are considered as a design of exploitation of unorganized agricultural labour and a human rights issue. Of late, the imperative of promoting the interests of agricultural and other labour households is felt in the welfare states. Following the universally accepted paradigm of addressing the plight of workers, the government of India ventured to intervene in the labour market and regulate all wages including agricultural wages. It enacted the minimum wages act, 1948 and periodic upward revisions have been made in the floor wage over the years. The states in India have also fixed minimum wages for all workers and agricultural labour and effected revisions therein periodically through appropriate legislation.

\subsection{Myths and Reality}

With this background it is worthwhile to examine the state of labour market and wages in contemporary agriculture. Needless to say, the subsistence and efficiency wage theories are vague as they beg the questions such as how much wage can meet the needs of subsistence and how much of it is necessary for efficiency? Both do not have any definite answer. The marginal productivity theory is a curiosom in the agricultural labour market because marginal product of labour is highly seasonal, (Lucas, 1987), difficult to compute and is never zero. The minimum wage law, despite all good intentions, has been proved redundant in many instances as the prevailing agricultural wage remains at a level above the statutory minimum.

The structural changes in the national and state economies, large scale migration of labour from agriculture and operation of the rural development and poverty alleviation programmes have systematically reduced the relative importance of agriculture in labour allocation decisions of rural households. Consequently, there has been considerable reduction in labour supply to agriculture. On the contrary, the spread of advanced farm technology, increase in cropping intensity, growing importance of timely farming operations, and a remarkable shift in agriculture from a family-labour based way of life kind of activity to a business enterprise have significantly increased the demand for farm labour. In such view of things agriculture is facing acute labour shortage and the notions of surplus rural labour and zero marginal product and opportunity cost of labour have become misnomers.

The agricultural labour market is showing symptoms of monopoly and monopsony and the wage rate is determined by the market forces of demand for and supply of labour. The wage rate in agriculture, in many regions, rules much above the level postulated by the subsistence, efficiency wage and marginal productivity theories and dictated by minimum wage laws. A new development in agriculture has been the payment of hourly and piece wages to workers. This indicates a resurgence of the neo-classical apparatus in explaining wage determination in agriculture (Bardhan, 1973, 1977; Sukhatme, 1978, Bardhan, 1979, 1979a; Rosenzweig, 1978, 1980; Vaidyanathan, 1980; Ahmed, 1981; Lal, 1984; Binswanger and Rosenzweig, 1984; Lucas, 1997) with relatively steeper demand and supply schedules of labour. Contemporary agricultural labour market posits a situation in which labour supply represents the shorter side (of the labour market) and labour can be a growthinhibiting factor for agricultural growth.

\section{Results and Discussion}

\subsection{Empirics of Labour Market and Wage Formation in Agriculture}

Demand and supply of labour and real wages in practical agriculture merit analysis. A proper understanding of the determinants of demand and supply of labour to agriculture and the relative role of demand and supply forces in wage formation in the farm sector are the prerequisites of sound agricultural policy.

\subsubsection{Demand for Labour}

In agriculture demand for labour comes from two categories of farm households. They are (i) the households with large acreage of agricultural land who use hired workers with very little family labour and (ii) those with small amounts of land who use family labour and small number of paid labour. Some households in both categories have their members working in urban areas as migrant labour. The demand for labour was found to have been influenced by five sets of factors such as (a) the pattern of distribution of agricultural land, (b) the 
extent of tenancy, (c) the use of labour-using advanced farm technology and cropping and intercultural practices, (d) the wage rate and (e) labour outmigration.

In order to estimate the demand for labour in agriculture in the study area we have made two assumptions. We assume a closed agricultural labour market which means that hiring workers across adjacent villages is rare and can be ignored. Secondly, we estimated the month-wise demand for labour on a per acre basis for Kharif paddy (May to December) assuming a given art of cultivation for all the sample households. Relevant data are presented in Table-1.

It can be seen from the table that labour requirement is responsive to the type of agricultural activity and it varies across months according to activities. The demand for labour is the highest (17 person days/acre) for weeding and fertilizer application activities undertaken in September. Crop cutting, carrying and heaping works carried out in November rank second with 15 person days per acre which is followed by thrashing, harvesting and storing in December ( 9 person days per acre). The total labour demand per acre is estimated at 56 person days.

Table- 1:Month-wise Requirement of Labour for Kharif Paddy

\begin{tabular}{|c|c|c|}
\hline Month & Major Activity & $\begin{array}{c}\text { Labour Requiremet in Person days } \\
\text { per acre }\end{array}$ \\
\hline $\mathbf{1}$ & $\mathbf{2}$ & $\mathbf{3}$ \\
\hline May & Land Preparation and Ploughing & 3 \\
\hline June & Ploughing, Leveling and Sowing & 4 \\
\hline July & Beusaning-Intercultural operation & 3 \\
\hline August & Beusaning-Intercultural operation and & 17 \\
\hline September & Wertilizer application & 3 \\
\hline October & Weed cutting and Pesticide spraying & 15 \\
\hline November & Crop cutting, Carrying and Heaping & 9 \\
\hline December & Thrashing and Harvesting & $\mathbf{5 6}$ \\
\hline
\end{tabular}

Source-Primary Survey

\subsubsection{Supply of Labour to Agriculture}

The supply of labour to agriculture comes from three sources: the large and medium farm households who use some amount of family labour on their farms, the small farm households who use large amounts of family labour on their farms and work as paid labor on others' farms, and agricultural labour households. Some households from each of these three categories have been observed to have sent their family members to urban centres as migrant workers. Among the small farm and agricultural labour households, the supply of wage workers to agriculture is more from the non-migrant households. A highly skewed land distribution, a low incidence of tenancy and a large proportion of agricultural workers in the total working population make a large supply of workers to agriculture possible. The level of agricultural wages can also be a factor on the supply side. The age, sex and activity status of persons given in Table-2 and the occupational structure of workers (16-63 age group) shown in Table-3 provide valuable information in respect of supply of labour to agriculture.

Table-2: Age, Sex and Activity Status of Households

\begin{tabular}{|c|c|c|c|c|c|c|c|c|c|c|c|c|c|c|c|}
\hline \multirow[t]{4}{*}{ Year } & \multirow{4}{*}{$\begin{array}{c}\text { No of } \\
\text { HH }\end{array}$} & \multicolumn{11}{|c|}{ Age,Sex and Activity Status } & \multirow{4}{*}{$\begin{array}{c}\text { Total } \\
\text { Population }\end{array}$} & \multirow{4}{*}{$\begin{array}{c}\text { Sex } \\
\text { Ratio }\end{array}$} & \multirow{4}{*}{$\begin{array}{c}\text { Dependency } \\
\text { Ratio }\end{array}$} \\
\hline & & \multicolumn{3}{|c|}{$0-15$} & \multicolumn{8}{|c|}{ 16-63 } & & & \\
\hline & & \multirow{2}{*}{ Male } & \multirow[t]{2}{*}{ Female } & \multirow[t]{2}{*}{ All } & \multicolumn{4}{|c|}{ Male } & \multicolumn{4}{|c|}{ Female } & & & \\
\hline & & & & & Study & Idle & Work & $\begin{array}{c}\text { Tota } \\
\text { l }\end{array}$ & Study & $\begin{array}{c}\text { HH } \\
\text { Work }\end{array}$ & $\begin{array}{l}\text { Other } \\
\text { work }\end{array}$ & Total & & & \\
\hline 1 & 2 & 3 & 4 & 5 & 6 & 7 & 8 & 9 & 10 & 11 & 12 & 13 & 14 & 15 & 16 \\
\hline 2002 & 280 & 188 & 172 & $\begin{array}{c}360 \\
(26.87)\end{array}$ & $\begin{array}{c}26 \\
(5.35)\end{array}$ & $\begin{array}{c}44 \\
(9.05)\end{array}$ & $\begin{array}{c}416 \\
(85.60)\end{array}$ & $\begin{array}{c}486 \\
(100)\end{array}$ & $\begin{array}{c}24 \\
(4.86)\end{array}$ & $\begin{array}{c}438 \\
(88.66)\end{array}$ & $\begin{array}{c}32 \\
(6.48)\end{array}$ & $\begin{array}{c}494 \\
(100)\end{array}$ & 1340 & 1016 & 1.99 \\
\hline 2007 & 289 & 192 & 182 & $\begin{array}{c}374 \\
(25.05) \\
\end{array}$ & $\begin{array}{c}28 \\
(5.03)\end{array}$ & $\begin{array}{c}51 \\
(9.17)\end{array}$ & $\begin{array}{c}477 \\
(85.79) \\
\end{array}$ & $\begin{array}{c}556 \\
(100)\end{array}$ & $\begin{array}{c}32 \\
(5.68)\end{array}$ & $\begin{array}{c}487 \\
(86.50)\end{array}$ & $\begin{array}{c}44 \\
(7.81)\end{array}$ & $\begin{array}{c}563 \\
(100)\end{array}$ & 1493 & 1012 & 1.86 \\
\hline 2012 & 300 & 210 & 198 & $\begin{array}{c}408 \\
(25.87)\end{array}$ & $\begin{array}{c}33 \\
(5.66)\end{array}$ & $\begin{array}{c}62 \\
(10.63)\end{array}$ & $\begin{array}{c}488 \\
(83.70)\end{array}$ & $\begin{array}{c}583 \\
(100)\end{array}$ & $\begin{array}{c}42 \\
(7.17)\end{array}$ & $\begin{array}{c}474 \\
(80.89)\end{array}$ & $\begin{array}{c}70 \\
(11.94)\end{array}$ & $\begin{array}{c}586 \\
(100)\end{array}$ & 1577 & 1005 & 1.82 \\
\hline
\end{tabular}

Source: Primary Survey

Figures in Parentheses indicate percentages to Total

Figures in bracket in column.5 show percentages to total population given in column 14

The table reveals a favourable sex ratio with females out numbering males and the ratio declining over the years from 1016 in 2002 to 1012 in 2007 and 1005 in 2012. The proportion of population in the 0-15 age 
group is roughly 26 per cent and about 6 per cent of males and 7 per cent of females in the 16 plus age group are studying. Quite unsurprisingly, females in the 16-63 age group are confined to domestic work but the proportion has declined from 88.66 per cent in 2002 to 86.5 per cent in 2007 and 80.89 per cent in 2012. An alarming fact is that a sizeable number of male population in the 16-63 age group, (10.63 per cent) is not appearing in the labour market for any work and their percentage is increasing. The obvious outcome of a bottom heavy age structure, concentration of women in domestic work and a significant proportion of prime age male population preferring to remain idle is a high dependency load of around 2 and is indicative of a scarcity of agricultural workers.

Table-3: Occupational Pattern of Workers

\begin{tabular}{|c|c|c|c|c|c|c|c|c|c|c|c|c|}
\hline \multirow[t]{3}{*}{ Year } & \multicolumn{4}{|c|}{ Workers in Agriculture } & \multicolumn{3}{|c|}{$\begin{array}{c}\text { Workers in Non- } \\
\text { Agricultural Activities }\end{array}$} & \multirow{3}{*}{$\begin{array}{c}\text { Out- } \\
\text { migrants } \\
\text { in urban } \\
\text { Non-Farm } \\
\text { Sector } \\
\text { Male }\end{array}$} & \multicolumn{4}{|c|}{ All workers } \\
\hline & \multicolumn{2}{|c|}{ Male } & \multirow[t]{2}{*}{ Female } & \multirow[t]{2}{*}{ Total } & \multirow[t]{2}{*}{ Male } & \multirow[t]{2}{*}{ Female } & \multirow[t]{2}{*}{ Total } & & \multirow[t]{2}{*}{ Agri. } & \multirow{2}{*}{$\begin{array}{l}\text { Non- } \\
\text { Agr(R) }\end{array}$} & \multirow{2}{*}{$\begin{array}{l}\text { Non- } \\
\text { Agri(U) }\end{array}$} & \multirow[t]{2}{*}{ Total } \\
\hline & $\begin{array}{c}\text { Age } \\
16-35\end{array}$ & $\begin{array}{c}\text { Age } \\
\text { 36-63 }\end{array}$ & & & & & & & & & & \\
\hline 1 & 2 & 3 & 4 & 5 & 6 & 7 & 8 & 9 & 10 & 11 & 12 & 13 \\
\hline 2002 & $\begin{array}{c}53 \\
(13.84\end{array}$ & $\begin{array}{c}318 \\
(83.03)\end{array}$ & $\begin{array}{c}12 \\
(3.13)\end{array}$ & $\begin{array}{c}383 \\
(100)\end{array}$ & $\begin{array}{c}31 \\
(60.78)\end{array}$ & $\begin{array}{c}20 \\
(39.22)\end{array}$ & $\begin{array}{c}51 \\
(100)\end{array}$ & $\begin{array}{c}84 \\
(17.28)\end{array}$ & $\begin{array}{c}383 \\
(73.94)\end{array}$ & $\begin{array}{c}51 \\
(9.85)\end{array}$ & $\begin{array}{c}84 \\
(16.22)\end{array}$ & $\begin{array}{c}518 \\
(100)\end{array}$ \\
\hline 2007 & $\begin{array}{c}23 \\
(6.05) \\
\end{array}$ & $\begin{array}{c}341 \\
(89.74)\end{array}$ & $\begin{array}{c}16 \\
(4.21)\end{array}$ & $\begin{array}{c}380 \\
(100)\end{array}$ & $\begin{array}{c}85 \\
(75.22)\end{array}$ & $\begin{array}{c}28 \\
(24.78)\end{array}$ & $\begin{array}{c}113 \\
(100)\end{array}$ & $\begin{array}{c}107 \\
(19.24)\end{array}$ & $\begin{array}{c}380 \\
(63.33)\end{array}$ & $\begin{array}{c}113 \\
(18.83)\end{array}$ & $\begin{array}{c}107 \\
(17.83)\end{array}$ & $\begin{array}{c}600 \\
(100)\end{array}$ \\
\hline 2012 & $\begin{array}{c}5 \\
(1.39)\end{array}$ & $\begin{array}{c}325 \\
(90.28)\end{array}$ & $\begin{array}{c}30 \\
(8.33)\end{array}$ & $\begin{array}{c}360 \\
(100)\end{array}$ & $\begin{array}{c}114 \\
(74.02)\end{array}$ & $\begin{array}{c}40 \\
(25.98)\end{array}$ & $\begin{array}{c}154 \\
(100)\end{array}$ & $\begin{array}{c}139 \\
(23.84)\end{array}$ & $\begin{array}{c}360 \\
(55.13)\end{array}$ & $\begin{array}{c}154 \\
(23.58)\end{array}$ & $\begin{array}{c}139 \\
(21.29)\end{array}$ & $\begin{array}{c}653 \\
(100)\end{array}$ \\
\hline
\end{tabular}

Source: Primary Survey

Figures in parentheses indicate percentages to respective totals

Figures in parentheses in Col.9are percentages to total male population in the 16-63 age group shown in col. 9 of Table-2 R-Rural, U-Urban

Significant changes have taken place in the occupational pattern of workers at the village level. The absolute number of male workers in agriculture has declined from $371(53+318)$ in 2002 to $364(23+341)$ in 2007 and $330(5+325)$ in 2012 and the number of prime age male agricultural workers (16-35 age group) has declined even faster. The share of male workers in total agricultural workers has reduced consistently from 96.87 per cent in 2002 to 95.79 per cent in 2007 and 91.67 per cent in 2012 and that in the prime age group has lowered at a higher rate from 13.84 per cent to 6.05 per cent and 1.39 per cent respectively. This situation reflects a kind of senilitisation and feminization of agricultural workforce. Again, considering all workers as a whole, the share of agricultural workers in total workers has declined markedly from 73.94 per cent in 2002 to 63.33 per cent in 2007 and 55.13 per cent in 2012. An increasing number and a rising percentage of male workers have migrated to urban centres (col.9) and have shifted to non- agricultural activities within the rural areas itself( Col.8 and 9or 11 and 12).This means that agriculture has been fast losing its importance as a source of employment for workers in the rural areas. Our results fit well with the overall employment scenario at the macro level and are indicative of ever reducing supply of labour to agriculture.

\subsubsection{Supply- Demand Gap and Missing Labour in Agriculture}

With a large demand for labour in agriculture following adoption of advanced farm technology, multiple cropping practices and intense interculture and a falling supply, the agriculturists are facing acute shortage of farm labour. To have a meaningful analysis of the problem we have estimated the magnitude of demand- supply gap in agricultural labour market by aggregating the person days of labour demanded and supplied across all farm households in the sample villages for kharif paddy. Relevant data have been given in Table-4.

Table-4: Supply- Demand Gap in Agricultural Labour

\begin{tabular}{|c|c|c|c|}
\hline Year & Requirement & Availability & Demand-Supply Gap \\
\hline $\mathbf{1}$ & $\mathbf{2}$ & $\mathbf{3}$ & $\mathbf{4}$ \\
\hline $\mathbf{2 0 0 2}$ & 54544 & $33348(61.14)$ & $21196(38.86)$ \\
\hline $\mathbf{2 0 0 7}$ & 54824 & $29474(53.76)$ & $25350(46.24)$ \\
\hline $\mathbf{2 0 1 2}$ & 55020 & $26528(48.22)$ & $28492(51.78)$ \\
\hline
\end{tabular}

Source: Primary Survey

Figures in parentheses indicate percentages to total of column 2

It can be read off the table that in raising the kharif paddy crop, 54544 person days of labour were required in 2002, which increased to 54,824 person days in 2007 and 55,020 person days in 2012 against the availability of 33,348 person days, 29,474 person days and 26,528 person days of labour in the respective years. 
The demand-supply gap amounted to 21,196 person days in 2002, 25,350 person days in 2007 and 28,492 person days in 2012 which constituted 38.86 per cent, 46.24 per cent and 51.78 percent of requirement in those years respectively. The demand-supply gap has been persistently increasing and is observed to be very high in the peak periods of intense agricultural activity. This is consistent with our assertion of acute labour shortage in agriculture. The factors responsible for growing demand- supply gap in agricultural labour as reported by the farm households in the sample villages are presented in Table-5.

Table -5: Causes of Labor Shortage in Agriculture

\begin{tabular}{|c|c|c|c|c|}
\hline Causes & Migrant HH & Returned-Migrant HH & Non-Migrant HH & All HH \\
\hline $\mathbf{1}$ & $\mathbf{2}$ & $\mathbf{3}$ & $\mathbf{4}$ & $163(54.33)$ \\
\hline Migration of Labour & $55(55.00)$ & $27(54.00)$ & $81(54.00)$ & $76(25.33)$ \\
\hline $\begin{array}{c}\text { Food Security } \\
\text { Programmes for BPL } \\
\text { Families }\end{array}$ & $25(25.00)$ & $12(24.00)$ & $21(14.00)$ & $44(14.66)$ \\
\hline $\begin{array}{c}\text { Preference for non- } \\
\text { farm work }\end{array}$ & $15(15.00)$ & $8(16.00)$ & $09(6.00)$ & $17(5.66)$ \\
\hline $\begin{array}{c}\text { Negative attitude } \\
\text { towards Agriculture }\end{array}$ & $05(5.00)$ & $03(6.00)$ & $\mathbf{1 5 0 ( 1 0 0 . 0 0 )}$ & $\mathbf{3 0 0 ( 1 0 0 )}$ \\
\hline Total & $\mathbf{1 0 0 ( 1 0 0 . 0 0 )}$ & $\mathbf{5 0 ( 1 0 0 . 0 0 )}$ & & \\
\hline
\end{tabular}

Source: Primary Survey

Figures in Parentheses indicate Percentage to Total

Movement of labour out of agriculture has been cited as the most important cause of labour shortage in agriculture and 54 per cent of respondents reported it as their first response reason. Food security programmes for the BPL households i.e. provision of $25 \mathrm{Kgs}$ of rice at Rs $2 / \mathrm{kg}$, recently lowered to $\mathrm{Re} 1 / \mathrm{kg}$, implemented in Odisha has been given as the second cause with 25 per cent of the surveyed households indicating it as their first response cause. Strong preferences for non-agricultural works in the rural areas and a negative attitude towards agriculture have been cited as the other causes. A similar pattern of response has been observed across the three categories of households covered under the study. Two things surfaced in course of focus group discussions (FGDs) held with the people in the sample villages. First, people are getting increasingly disinterested in and are withdrawing from agriculture because they consider it as relatively more cumbersome and less income yielding, while the well-to-do sections view working in agriculture as a low esteem job. The problem of workers opting out causing acute labour scarcity in agriculture can be paraphrased as "missing labour". Second, many came out in the open against the government's heavily subsidized rice programme which induces people to enjoy free riding and stay away from the labour market.

\subsubsection{Wage Rate in Agriculture}

One obvious outcome of the prevailing large excess demand situation in the agricultural labour market has been a remarkable increase in the wage rate. Valuable information is presented in Table- 6 .

Table-6: Wage Rate in Agriculture (in rupees at Current and Constant 1986-87 prices)

\begin{tabular}{|c|c|c|c|c|c|c|c|}
\hline \multirow[t]{3}{*}{ Year } & \multicolumn{4}{|c|}{ Wage rate (Current Price) } & \multicolumn{3}{|c|}{ Wage Rate (Constant Price) } \\
\hline & \multicolumn{3}{|c|}{ Prevailing Wage } & \multirow{2}{*}{$\begin{array}{l}\text { Minimum } \\
\text { wage }\end{array}$} & \multirow{2}{*}{$\begin{array}{c}\text { Prevailing } \\
\text { Wage (Male) }\end{array}$} & \multirow{2}{*}{$\begin{array}{l}\text { Minimum } \\
\text { Wage }\end{array}$} & \multirow{2}{*}{$\begin{array}{c}\text { Percentage } \\
\text { Variation }\end{array}$} \\
\hline & Female & Male & $\begin{array}{c}\text { Percentage } \\
\text { Variation }\end{array}$ & & & & \\
\hline 1 & 2 & 3 & 4 & 5 & 6 & 7 & 8 \\
\hline 2002 & 60 & 75 & 20.00 & 50 & 23.81 & 15.87 & 50.03 \\
\hline 2007 & 95 & 120 & 20.83 & 70 & 29.85 & 17.41 & 71.45 \\
\hline 2012 & 175 & 220 & 20.45 & 150 & 33.84 & 23.07 & 46.68 \\
\hline
\end{tabular}

Sources: 1) Primary Survey

2) Department of Labour and Employment, Government of Odisha, Notification on Minimum Wages of Labour in Various Years

Note-The Wage rate at constant prices have been estimated by adjusting the money wage to the price index data contained in Labour Bureau, Govt. of India Statistics

As can be seen from the table, the daily wage rate at constant prices (the real wage rate) has increased substantially from Rs.23.81 in 2002 to Rs. 29.85 in 2007 and Rs 33.84 in 2012. The increase is much higher when we consider the wage rate at current prices i.e., Rs 75, Rs 120 and Rs 220 for the respective years. The wage rate prevailing in all the three reference years were also much above the mandated minimum wages and the former were estimated to be 50.03 per cent, 71.45 per cent and 46.68 per cent higher than the latter in 2002, 2007 and 2012 respectively. The upward trend in the farm wage rate indicates that the agricultural sector has crossed the Lewisian turning point and it invalidates the hypothesis that labour is immiserising. Another 
important fact is the persistence of large gender inequality in agricultural wage rate with women being paid about 20 per cent less than males which mean that minimum wage laws have not succeeded in equalizing wages across gender.

\subsubsection{Explanatory Variables}

The problem of labour scarcity and wage increase has been pervasive in Odishan agriculture. The famers are complaining of unprofitability of agriculture owing to increasing farm costs in agriculture following rise in farm input prices including wages relative to product (paddy) prices. They have started protest movements in different parts of the state, the latest being on 25 March, 2013 at the state capital-Bhubaneswar demanding, among other things, higher paddy prices to compensate for the rising farm costs. They are even demanding pension. But why are agricultural wages increasing? A cursory probe reveals that the factors responsible for reduced flow of labour to agriculture in the face of an increasing labour demand have created a large excess demand scenario pushing up wages consistently over the years. A brief summary of the causative forces as perceived by the respondents is given in Table- 7 .

Tabl-7: Causes of Wage Increase

\begin{tabular}{|c|c|c|c|c|}
\hline Causes & Migrant HH & Returned Migrant HH & Non-Mirant HH & All HH \\
\hline $\mathbf{1}$ & $\mathbf{2}$ & $\mathbf{3}$ & $\mathbf{4}$ & $\mathbf{5}$ \\
\hline Migration & $63(63.00)$ & $29(58.00)$ & $86(57.33)$ & $82(27.33)$ \\
\hline $\begin{array}{c}\text { Food Security } \\
\text { Programmes }\end{array}$ & $32(32.00)$ & $14(28.00)$ & $36(24.00)$ & \\
\hline Migrants' Action & $05(05.0)$ & $07(14.00)$ & $28(18.67)$ & $40(13.33)$ \\
\hline Total & $100(100)$ & $50(100)$ & $150((100)$ & $300(100)$ \\
\hline
\end{tabular}

Source: Primary Survey

Figures in parentheses indicate percentages to Total

Agricultural wages differ from non-agricultural wages, but the two are interdependent and influence each other. Physically less demanding regular work opportunities and high non-farm wages in urban areas tend to draw workers from rural agriculture. The resultant labour shortages due to withdrawal from agriculture are forcing farmers to pay higher wages. 59.33 per cent of respondents have rated these as the cause of rising farm wages. The highly subsidized populist food security policy of the government supplying $25 \mathrm{kgs}$ of rice to all BPL families at RE $1 / \mathrm{kg}$ which enables them to obtain their monthly grain requirements with two-three days wage income has promoted complacency in them inducing them to stay away from the labour market. Those who offer for work compel the farmers to pay higher wages. 27.33 per cent of respondents cited it as the main cause of wage increase. Last but not the least important factor for many respondents has been the actions of migrants themselves who come to their village for a very few days during transplanting, beusaning, weed cutting, crop cutting and harvesting times and are in a hurry to complete the work by hiring workers at wages higher than the market wage rate. This has been given as the first response cause by 13.33 per cent. This pattern of response for causes of wage increase has been observed more or less uniformly across the three household categories covered in the study.

Three things need to be noted while passing .First and quite surprisingly, the argument that farm wages are rising because of the MNREGA implementation and minimum wage laws does not have any taker among the respondents. Agricultural wages stand much above the MNREGA wage and also the minimum wage. Second, agricultural wages respond more to reduced supply of labour than to increasing demand. Third, the processes operating in agricultural labour market have tended to raise the reservation wage of labour in the farm sector.

\subsection{Farm Costs and Productivity}

Labour shortage and wage rise entail a kind of labour market tightening in agriculture and can have two implications. First, they can promote greater use of high cost advanced farm technology and both wage hike and technology application are likely to raise cost of production. Second, the use of advanced technology is likely to raise the productivity of both land and labour which may result in lower unit costs than before. Thus viewed, agricultural costs and productivity are interlinked and the impact of labour market tightening on costs and productivity cannot be ascertained in isolation and a priori.

\subsubsection{Size and Composition of Farm Costs}

Agricultural Costs are of two kinds-fixed costs and variable costs or operational costs, and they include both explicit and implicit costs. In any assessment of productivity, unit costs and profitability in agriculture, operational costs get precedence over fixed costs for obvious reasons and since some of the farm inputs are 
owned by the household itself implicit costs cannot be overlooked. We have used eight components of operational costs such as charges for the use of labour, farm machinery, seed, fertiliser, pesticides, livestock, irrigation, and working capital in our analysis. Estimates in respect of each of them per acre of land in the cultivation of Kharif paddy as obtained from our survey are presented in Table-8.

Table-8: Cost Structure in Agriculture (in rupees per acre at constant prices)

\begin{tabular}{|c|c|c|c|c|c|}
\hline Year & Cost Components & $\begin{array}{c}\text { Migrant } \\
\text { Households }\end{array}$ & $\begin{array}{c}\text { Returned Migrant } \\
\text { Households }\end{array}$ & $\begin{array}{c}\text { Non-Migrant } \\
\text { Households }\end{array}$ & All Households \\
\hline 1 & 2 & 3 & 4 & 4 & 6 \\
\hline \multirow{9}{*}{2002} & Labour & $787.30(42.36)$ & $819.04(45.23)$ & $822.22(46.01)$ & $809.52(44.51)$ \\
\hline & Fertilizer & $260.32(14.00)$ & $216.82(11.97)$ & $196.82(11.01)$ & $224.65(12.35)$ \\
\hline & Pesticides & $46.03(2.48)$ & $40(2.21)$ & $39.68(2.22)$ & $41.90(2.30)$ \\
\hline & Machinery & $412.70(22.20)$ & $291.75(16.11)$ & $285.71(16.00)$ & $330.05(18.15)$ \\
\hline & Livestock & $155.55(8.37)$ & $241.90(13.36)$ & $238.09(13.32)$ & $211.85(11.65)$ \\
\hline & Irrigation & $57.14(3.07)$ & $50(2.76)$ & $50.79(2.84)$ & $52.64(2.89)$ \\
\hline & Seed & $76.19(4.10)$ & $75.07(4.15)$ & $71.11(3.98)$ & $74.12(4.07)$ \\
\hline & Cost of Borrowing & $63.49(3.41)$ & $76.19(4.21)$ & $82.54(4.62)$ & $74.07(4.07)$ \\
\hline & Total & $1858.72(100)$ & $1810.77(100)$ & $1786.96(100)$ & $1818.80(100)$ \\
\hline \multirow{9}{*}{2007} & Labour & $873.13(41.25)$ & $883.08(44.86)$ & $930.35(47.04)$ & $895.52(44.31)$ \\
\hline & Fertilizer & $298.50(14.10)$ & $261.94(13.30)$ & $248.76(12.58)$ & $269.73(13.35)$ \\
\hline & Pesticides & $49.75(2.35)$ & $48.50(2.46)$ & $39.80(2.01)$ & $46.02(2.28)$ \\
\hline & Machinery & $559.70(26.44)$ & $393.03(19.98)$ & $385.57(19.50)$ & $446.10(22.07)$ \\
\hline & Livestock & $99.50(4.70)$ & $149.75(7.61)$ & $149.25(7.55)$ & $132.83(6.57)$ \\
\hline & Irrigation & $62.19(2.94)$ & $63.68(3.24)$ & $62.19(3.14)$ & $62.69(3.10)$ \\
\hline & Seed & $99.50(4.70)$ & $74.87(3.80)$ & $74.63(3.77)$ & $83(4.11)$ \\
\hline & Cost of Borrowing & $74.63(3.52)$ & $93.53(4.75)$ & $87.06(4.40)$ & $85.07(4.21)$ \\
\hline & Total & $2116.90(100)$ & 1968.38(100) & 1977.61(100) & $2020.96(100)$ \\
\hline \multirow{9}{*}{2012} & Labour & $849.24(40.13)$ & $913.85(44.75)$ & $969.23(46.86)$ & $910.77(43.88)$ \\
\hline & Fertilizer & $327.69(15.49)$ & $278.30(13.63)$ & $266.16(12.87)$ & $290.72(14.00)$ \\
\hline & Pesticides & $53.85(2.54)$ & $41.23(2.02)$ & $38.47(1.86)$ & $44.52(2.14)$ \\
\hline & Machinery & $615.38(29.08)$ & $501.69(24.57)$ & $492.30(23.80)$ & $536.46(25.85)$ \\
\hline & Livestock & $38.46(1.82)$ & $72.15(3.53)$ & $69.23(3.34)$ & $59.95(2.89)$ \\
\hline & Irrigation & $58.46(2.76)$ & $51.54(2.52)$ & $52.30(2.53)$ & $54.10(2.61)$ \\
\hline & Seed & $103.85(4.91)$ & $96.92(4.75)$ & $96.15(4.65)$ & $98.97(4.77)$ \\
\hline & Cost of Borrowing & $69.23(3.27)$ & $86.46(4.23)$ & $84.61(4.09)$ & $80.10(3.86)$ \\
\hline & Total & 2116.16(100) & 2042.14(100) & $2068.45(100)$ & $2075.59(100)$ \\
\hline
\end{tabular}

Source: Primary Survey

Figures in Parentheses indicate percentages to Total

As can be seen from the table, the overall operational cost of cultivation has increased substantially from Rs 1818.80 in 2002 to Rs 2020.96 in 2007 and 2075.59 in 2012. A cursory look at the composition of costs reveals that the cost on account of labour, machinery, fertiliser and seeds have increased remarkably but that of livestock has declined significantly. On the other hand, the charges due to interest on borrowings, irrigation and pesticides have increased between 2002 and 2007 but declined slightly during 2007-2012. Since interest, irrigation charges, cost of pesticides and payment for livestock are not prominent components of the overall cost, both individually and combinedly, they have been overpowered by higher costs due to labour, machinery, fertiiliser and seeds leading to a consistent increase in cost per acre.

Component wise analysis depicts that wages continue to be the single largest item of farm costs accounting for about 44 per cent of total operational costs. Its share in total costs has declined marginally from 44.51 per cent in 2002 to 44.31 per cent in 2007 and 43.88 per cent in 2012. But in absolute terms it has been increasing due to substantial wage hike despite falling use of labour. This suggests that agriculture still remains a labour-intensive activity and the scope of mechanisation remains limited. Next to wages come the charges due to machinery which continue to shoot up over the years both in absolute and relative terms. Its share has increased from 18.15 per cent in 2002 to 22.07 per cent in 2007 and 25.85 per cent in 2012. The shares of fertilizer and seeds have registered some increase but that of draught labour has declined remarkably from 11.65 per cent in 2002 to 6.57 per cent in 2007 and 2.89 per cent in 2012. The shares of interest, irrigation charges and pesticides have remained roughly constant at 4 per cent, 3 per cent and 2 per cent respectively over the years under study. This shift in the relative contribution of individual items to total farm costs suggests that agriculture is gradually commercializing and modernizing.

A similar picture of overall costs of production and shift in the relative position of individual items is discernible across the three categories of farm households .However, the decline in the relative share of labour 
cost and the increase in that of machinery charges and fertiliser cost are little higher in the case of the migrant households than for the other households.

\subsubsection{Productivity in Agriculture}

Assuming that land, labour and other resource inputs have a more or less stable relationship in the production process, we define agricultural productivity in terms of output of Kharif paddy per cropped acre and person days of labour used in cultivation. Given the unique interdependence of costs and productivity, we have attempted to link wage rate, labour use and overall cost per acre, output per acre and personday of labour, and cost per unit of output. Relevant data are presented in Table-9. We have observed a persistent decline in person day of labour used per cropped area and a consistent increase in the output of Kharif paddy both per acre and person days of labour used in agriculture. While labour use per acre has declined from 34.13 person days in 2002 to 30.19 person days in 2007 and 27 person days in 2012,output per acre has increased from 10.41 quintals in 2002 to 12.27 quintals in 2007 and 14.42 quintals in 2012 and the same per person days of labour has gone up from 0.3 quintal to 0.41 quintal and 0.53 quintal respectively for the years under reference.

Table-9: Cost and Productivity in Agriculture

\begin{tabular}{|c|c|c|c|c|c|c|c|}
\hline Year & $\begin{array}{c}\text { Household } \\
\text { Category }\end{array}$ & $\begin{array}{c}\text { Farm wage } \\
\text { rate } \\
\text { (Rupees) }\end{array}$ & $\begin{array}{c}\text { Labour } \\
\text { used per } \\
\text { acre }\end{array}$ & $\begin{array}{c}\text { Cost of } \\
\text { Production } \\
\text { Per } \\
\text { acre(Rupees) }\end{array}$ & $\begin{array}{c}\text { Output Per } \\
\text { Acre } \\
\text { (Quintals) }\end{array}$ & $\begin{array}{c}\text { Output per } \\
\text { Persondays } \\
\text { of Labour } \\
\text { (Quintal) }\end{array}$ & $\begin{array}{c}\text { Average Cost of } \\
\text { Production per } \\
\text { quintal(Rupees) }\end{array}$ \\
\hline $\mathbf{1}$ & $\mathbf{2}$ & 3 & 4 & 5 & 6 & 7 & 8 \\
\hline \multirow{4}{*}{$\mathbf{2 0 0 2}$} & Migrants & 25.39 & 31 & 1858.72 & 11 & 0.35 & 168.97 \\
\cline { 2 - 8 } & $\begin{array}{c}\text { Returned } \\
\text { Migrants }\end{array}$ & 23.81 & 34.4 & 1810.77 & 10.25 & 0.30 & 176.66 \\
\cline { 2 - 8 } & $\begin{array}{c}\text { Non- } \\
\text { Migrants }\end{array}$ & 22.22 & 37 & 1786.96 & 10 & 0.27 & 178.70 \\
\cline { 2 - 8 } & All & 23.81 & 34.13 & 1818.80 & 10.41 & 0.30 & 174.71 \\
\hline \multirow{3}{*}{$\mathbf{2 0 0 7}$} & Migrants & 32.33 & 27 & 2116.91 & 13.2 & 0.49 & 160.37 \\
\cline { 2 - 8 } & $\begin{array}{c}\text { Returned } \\
\text { Migrants }\end{array}$ & 29.85 & 29.58 & 1968.38 & 12 & 0.41 & 164.70 \\
\cline { 2 - 8 } & $\begin{array}{c}\text { Non- } \\
\text { Migrants }\end{array}$ & 27.36 & 34 & 1977.61 & 11.6 & 0.34 & 170.48 \\
\cline { 2 - 8 } & All & 29.85 & 30.19 & 2020.96 & 12.27 & 0.41 & 164.84 \\
\hline \multirow{2}{*}{$\mathbf{2 0 1 2}$} & Migrants & 35.38 & 24 & 2116.15 & 15 & 0.62 & 141.07 \\
\cline { 2 - 8 } & $\begin{array}{c}\text { Returned } \\
\text { Migrants }\end{array}$ & 33.85 & 27 & 2042.15 & 14.25 & 0.53 & 143.30 \\
\cline { 2 - 8 } & $\begin{array}{c}\text { Non- } \\
\text { Migrants }\end{array}$ & 32.30 & 30 & 2068.46 & 14 & 0.46 & 147.75 \\
\cline { 2 - 8 } & All & 33.84 & 27 & 2075.59 & 14.42 & 0.53 & 144.94 \\
\hline
\end{tabular}

Source: Primary Survey

Note: Figures at column 3,5 and 8 are at constant 1986-87 prices

Although the per acre cost of production has increased significantly from 1818.80 in 2002 to Rs 2020.96 in 2007 and Rs. 2075.59 in 2012, the average cost per quintal of paddy has declined remarkably from Rs 174.71 in 2002 to Rs 164.84 in 2007 and Rs. 144.94 in 2012 on account of improvement in productivity of both land and labour. Adoption of mechanized farm practices, use of yield -raising agricultural inputs made possible by availability of simple tools, improved seeds , chemical fertiliser etc., and provision of electricity and irrigation have not only helped to moderate the negative effect of acute labour scarcity but also contributed to improved farm productivity.

A similar picture is obtained when we look at the situation across the three farm household categories. However, the performance of migrant households has been better than those of returned migrant households which are again a little better than those of the non-migrant households. This is probably because of differences in resource position of the households.

\subsection{Cropping Pattern and Land Utilisation}

In addition to selective mechanization and application of advanced technology, farmers have also effected some changes in cropping pattern as a strategy to cope with labour shortage and wage rise. Some have even left their land idle because of labour problems.

\subsubsection{Changes in Cropping Pattern}

Paddy, vegetables, grams and some other minor crops are grown by the farmers in the study area. They have introduced some changes in the cropping pattern to cope with labour problems. Table-10 contains valuable information on this issue. 
Table-10: Dynamics of Cropping Pattern Across Households (in acres)

\begin{tabular}{|c|c|c|c|c|c|c|c|c|c|c|c|c|c|c|c|c|}
\hline \multirow[t]{2}{*}{ Year } & \multirow{2}{*}{$\begin{array}{l}\text { Household } \\
\text { Category }\end{array}$} & \multicolumn{5}{|c|}{ Kharif } & \multicolumn{5}{|c|}{ Rabi } & \multicolumn{5}{|c|}{ All } \\
\hline & & Paddy & Grams & Veg. & others & Total & Paddy & Grams & Veg. & others & Total & Paddy & Grams & Veg. & others & Total \\
\hline 1 & 2 & 3 & 4 & 5 & 6 & 7 & 8 & 9 & 10 & 11 & 12 & 13 & 14 & 15 & 16 & 17 \\
\hline \multirow{4}{*}{2002} & Migrants & $\begin{array}{l}164.60 \\
(88.94)\end{array}$ & $\begin{array}{l}3.55 \\
(1.92)\end{array}$ & $\begin{array}{l}12.47 \\
(6.74)\end{array}$ & $\begin{array}{l}4.44 \\
(2.40)\end{array}$ & $\begin{array}{l}185.06 \\
(100)\end{array}$ & $\begin{array}{l}74.51 \\
(69.25)\end{array}$ & $\begin{array}{l}14.89 \\
(13.84)\end{array}$ & $\begin{array}{l}13.23 \\
(12.30)\end{array}$ & $\begin{array}{l}4.96 \\
(4.61)\end{array}$ & $\begin{array}{l}107.59 \\
(100)\end{array}$ & $\begin{array}{l}239.11 \\
(81.71)\end{array}$ & $\begin{array}{l}18.44 \\
(6.30)\end{array}$ & $\begin{array}{l}25.7 \\
(8.78)\end{array}$ & $\begin{array}{l}9.4 \\
(3.21)\end{array}$ & $\begin{array}{l}292.65 \\
(100)\end{array}$ \\
\hline & $\begin{array}{l}\text { Returned } \\
\text { Migrants }\end{array}$ & $\begin{array}{l}110 \\
(90.00)\end{array}$ & $\begin{array}{l}3.66 \\
(3.00)\end{array}$ & $\begin{array}{l}6.11 \\
(5.00)\end{array}$ & $\begin{array}{l}2.44 \\
(2.00)\end{array}$ & $\begin{array}{l}122.21 \\
(100)\end{array}$ & $\begin{array}{l}50.12 \\
(70.00)\end{array}$ & $\begin{array}{l}7.16 \\
(10.00)\end{array}$ & $\begin{array}{l}10.02 \\
(14.00)\end{array}$ & $\begin{array}{l}4.29 \\
(6.00)\end{array}$ & $\begin{array}{l}71.59 \\
(100)\end{array}$ & $\begin{array}{l}160.12 \\
(82.62)\end{array}$ & $\begin{array}{l}10.82 \\
(5.58)\end{array}$ & $\begin{array}{l}16.13 \\
(8.33)\end{array}$ & $\begin{array}{l}6.73 \\
(3.47)\end{array}$ & $\begin{array}{l}193.8 \\
(100)\end{array}$ \\
\hline & $\begin{array}{c}\text { Non- } \\
\text { migrants }\end{array}$ & $\begin{array}{l}572.08 \\
(90.30)\end{array}$ & $\begin{array}{l}18.43 \\
(2.91)\end{array}$ & $\begin{array}{l}30.73 \\
(4.85)\end{array}$ & $\begin{array}{l}12.29 \\
(1.94)\end{array}$ & $\begin{array}{l}633.53 \\
(100)\end{array}$ & $\begin{array}{l}279.96 \\
(70.09)\end{array}$ & $\begin{array}{l}37.71 \\
(9.44)\end{array}$ & $\begin{array}{l}56.61 \\
(14.17)\end{array}$ & $\begin{array}{l}25.13 \\
(6.29)\end{array}$ & $\begin{array}{l}399.41 \\
(100)\end{array}$ & $\begin{array}{l}852.04 \\
(82.49)\end{array}$ & $\begin{array}{l}56.14 \\
(5.43)\end{array}$ & $\begin{array}{l}87.34 \\
(8.46)\end{array}$ & $\begin{array}{l}37.42 \\
(3.62)\end{array}$ & $\begin{array}{l}1032.94 \\
(100)\end{array}$ \\
\hline & All & $\begin{array}{l}846.68 \\
(90.00)\end{array}$ & $\begin{array}{l}25.64 \\
(2.73)\end{array}$ & $\begin{array}{l}49.31 \\
(5.24)\end{array}$ & $\begin{array}{l}19.17 \\
(2.03)\end{array}$ & $\begin{array}{l}940.8 \\
(100)\end{array}$ & $\begin{array}{l}404.59 \\
(69.93)\end{array}$ & $\begin{array}{l}59.76 \\
(10.33)\end{array}$ & $\begin{array}{l}79.86 \\
(13.80)\end{array}$ & $\begin{array}{l}34.38 \\
(5.94)\end{array}$ & $\begin{array}{l}578.59 \\
(100)\end{array}$ & $\begin{array}{l}1251.27 \\
(82.36)\end{array}$ & $\begin{array}{l}85.4 \\
(5.62)\end{array}$ & $\begin{array}{l}129.17 \\
(8.50)\end{array}$ & $\begin{array}{l}53.55 \\
(3.52)\end{array}$ & $\begin{array}{l}1519.39 \\
(100)\end{array}$ \\
\hline \multirow{4}{*}{2007} & Migrants & $\begin{array}{l}163.66 \\
(86.07)\end{array}$ & $\begin{array}{l}7.56 \\
(3.98)\end{array}$ & $\begin{array}{l}15.13 \\
(7.96)\end{array}$ & $\begin{array}{l}3.78 \\
(1.99)\end{array}$ & $\begin{array}{l}190.13 \\
(100)\end{array}$ & $\begin{array}{l}68.39 \\
(60.99)\end{array}$ & $\begin{array}{l}14.58 \\
(13.0)\end{array}$ & $\begin{array}{l}21.88 \\
(19.51)\end{array}$ & $\begin{array}{l}7.29 \\
(6.50)\end{array}$ & $\begin{array}{l}112.14 \\
(100)\end{array}$ & $\begin{array}{l}232.05 \\
(76.73)\end{array}$ & $\begin{array}{l}22.14 \\
(7.32)\end{array}$ & $\begin{array}{l}37.01 \\
(12.29)\end{array}$ & $\begin{array}{l}11.07 \\
(3.66)\end{array}$ & $\begin{array}{l}302.27 \\
(100)\end{array}$ \\
\hline & $\begin{array}{l}\text { Returned } \\
\text { Migrants }\end{array}$ & $\begin{array}{l}107.72 \\
(88.64)\end{array}$ & $\begin{array}{l}3.95 \\
(3.25)\end{array}$ & $\begin{array}{l}7.40 \\
(6.09)\end{array}$ & $\begin{array}{l}.46 \\
(2.02)\end{array}$ & $\begin{array}{l}121.53 \\
(100)\end{array}$ & $\begin{array}{l}42.14 \\
(59.75)\end{array}$ & $\begin{array}{l}10.77 \\
(15.27)\end{array}$ & $\begin{array}{l}11.75 \\
(16.66)\end{array}$ & $\begin{array}{l}5.87 \\
(8.32)\end{array}$ & $\begin{array}{l}70.53 \\
(100)\end{array}$ & $\begin{array}{l}149.86 \\
(78.03)\end{array}$ & $\begin{array}{l}14.72 \\
(7.66)\end{array}$ & $\begin{array}{l}19.15 \\
(9.97)\end{array}$ & $\begin{array}{l}8.33 \\
(4.34)\end{array}$ & $\begin{array}{l}192.06 \\
(100)\end{array}$ \\
\hline & $\begin{array}{c}\text { Non- } \\
\text { migrants }\end{array}$ & $\begin{array}{l}541.34 \\
(89.00)\end{array}$ & $\begin{array}{l}18.24 \\
(3.00)\end{array}$ & $\begin{array}{l}36.48 \\
(6.00)\end{array}$ & $\begin{array}{l}12.16 \\
(2.00)\end{array}$ & $\begin{array}{l}608.22 \\
(100)\end{array}$ & $\begin{array}{l}225.97 \\
(60.17)\end{array}$ & $\begin{array}{l}58 \\
(15.44)\end{array}$ & $\begin{array}{l}61.07 \\
(16.26)\end{array}$ & $\begin{array}{l}30.53 \\
(8.13)\end{array}$ & $\begin{array}{l}375.57 \\
(100)\end{array}$ & $\begin{array}{l}767.31 \\
(78)\end{array}$ & $\begin{array}{l}76.24 \\
(7.75)\end{array}$ & $\begin{array}{l}97.55 \\
(9.93)\end{array}$ & $\begin{array}{l}42.69 \\
(4.34)\end{array}$ & $\begin{array}{l}983.79 \\
(100)\end{array}$ \\
\hline & All & $\begin{array}{l}812.72 \\
(88.35) \\
\end{array}$ & $\begin{array}{l}29.75 \\
(3.23) \\
\end{array}$ & $\begin{array}{l}59.01 \\
(6.41) \\
\end{array}$ & $\begin{array}{l}18.40 \\
(2.00)\end{array}$ & $\begin{array}{l}919.88 \\
(100)\end{array}$ & $\begin{array}{l}336.5 \\
(60.28) \\
\end{array}$ & $\begin{array}{l}83.35 \\
(14.93) \\
\end{array}$ & $\begin{array}{l}94.7 \\
(16.96)\end{array}$ & $\begin{array}{l}43.69 \\
(7.83) \\
\end{array}$ & $\begin{array}{l}558.24 \\
(100)\end{array}$ & $\begin{array}{l}1149.22 \\
(77.75)\end{array}$ & $\begin{array}{l}113.1 \\
(7.65) \\
\end{array}$ & $\begin{array}{l}153.71 \\
(10.40)\end{array}$ & $\begin{array}{l}62.09 \\
(4.20) \\
\end{array}$ & $\begin{array}{l}1478.12 \\
(100)\end{array}$ \\
\hline \multirow{4}{*}{2012} & Migrants & $\begin{array}{l}148 \\
(82.68)\end{array}$ & $\begin{array}{l}10 \\
(5.59)\end{array}$ & $\begin{array}{l}20 \\
(11.17\end{array}$ & $\begin{array}{l}01 \\
(0.56)\end{array}$ & $\begin{array}{l}179 \\
(100)\end{array}$ & $\begin{array}{l}52 \\
(52.53)\end{array}$ & $\begin{array}{l}16 \\
(16.66)\end{array}$ & $\begin{array}{l}30 \\
(30.30)\end{array}$ & $\begin{array}{l}01 \\
(1.01)\end{array}$ & $\begin{array}{l}99 \\
(100)\end{array}$ & $\begin{array}{l}200 \\
(71.94)\end{array}$ & $\begin{array}{l}26 \\
(9.35)\end{array}$ & $\begin{array}{l}50 \\
(17.99)\end{array}$ & $\begin{array}{l}2 \\
(0.72)\end{array}$ & $\begin{array}{l}278 \\
(100)\end{array}$ \\
\hline & $\begin{array}{l}\text { Returned } \\
\text { Migrants }\end{array}$ & $\begin{array}{l}97.5 \\
(85.53)\end{array}$ & $\begin{array}{l}5.5 \\
(4.82)\end{array}$ & $\begin{array}{l}9.5 \\
(8.33)\end{array}$ & $\begin{array}{l}1.5 \\
(1.32)\end{array}$ & $\begin{array}{l}114 \\
(100)\end{array}$ & $\begin{array}{l}32 \\
(50.79)\end{array}$ & $\begin{array}{l}13 \\
(20.63)\end{array}$ & $\begin{array}{l}15 \\
(23.81)\end{array}$ & $\begin{array}{l}3 \\
(4.76)\end{array}$ & $\begin{array}{l}63 \\
(100)\end{array}$ & $\begin{array}{l}129.5 \\
(73.16)\end{array}$ & $\begin{array}{l}18.5 \\
(10.45)\end{array}$ & $\begin{array}{l}24.5 \\
(13.84)\end{array}$ & $\begin{array}{l}4.5 \\
(2.54)\end{array}$ & $\begin{array}{l}177 \\
(100)\end{array}$ \\
\hline & $\begin{array}{c}\text { Non- } \\
\text { migrants }\end{array}$ & $\begin{array}{l}501 \\
(85.64)\end{array}$ & $\begin{array}{l}30 \\
(5.13)\end{array}$ & $\begin{array}{l}48 \\
(8.20)\end{array}$ & $\begin{array}{l}06 \\
(1.03)\end{array}$ & $\begin{array}{l}585 \\
(100)\end{array}$ & $\begin{array}{l}159 \\
(51.46)\end{array}$ & $\begin{array}{l}60 \\
(19.42)\end{array}$ & $\begin{array}{l}72 \\
(23.30)\end{array}$ & $\begin{array}{l}18 \\
(5.82)\end{array}$ & $\begin{array}{l}309 \\
(100)\end{array}$ & $\begin{array}{l}660 \\
(73.83)\end{array}$ & $\begin{array}{l}90 \\
(10.07)\end{array}$ & $\begin{array}{l}120 \\
(13.42)\end{array}$ & $\begin{array}{l}24 \\
(2.68)\end{array}$ & $\begin{array}{l}894 \\
(100)\end{array}$ \\
\hline & All & $\begin{array}{l}746.5 \\
(85.02) \\
\end{array}$ & $\begin{array}{l}45.5 \\
(5.18)\end{array}$ & $\begin{array}{l}77.5 \\
(8.83) \\
\end{array}$ & $\begin{array}{l}8.5 \\
(0.97)\end{array}$ & $\begin{array}{l}878 \\
(100)\end{array}$ & $\begin{array}{l}243 \\
(51.59)\end{array}$ & $\begin{array}{l}89 \\
(18.90)\end{array}$ & $\begin{array}{l}117 \\
(24.84)\end{array}$ & $\begin{array}{l}22 \\
(4.67)\end{array}$ & $\begin{array}{l}471 \\
(100)\end{array}$ & $\begin{array}{l}989.5 \\
(73.35) \\
\end{array}$ & $\begin{array}{l}134.5 \\
(9.97) \\
\end{array}$ & $\begin{array}{l}194.5 \\
(14.42) \\
\end{array}$ & $\begin{array}{l}30.5 \\
(2.26)\end{array}$ & $\begin{array}{l}1349 \\
(100) \\
\end{array}$ \\
\hline
\end{tabular}

Source: Primary Survey

Figures in Parentheses indicate percentages to Total

Veg.-Vegetables

Paddy has been observed to be the staple crop in the study area. The share of area under this crop has reduced slightly from 82.36 per cent in 2002 to 77.75 per cent in 2007 and 73.35 per cent in 2012 . The shares of land-intensive crops like vegatables and grams have increased over the years. While the share of area under vegetables has increased from 8.5 per cent to 10.4 per cent and 14.42 per cent in 2002,2007 and 2012 respectively that under grams has gone up from 5.62 per cent to 7.65 per cent and 9.97 per cent in the years in that order. A similar change is noticed in both Rabi and Kharif crops across the three household categories. But the shift is somewhat greater in the case of the migrant households relative to others and is so in the Rabi season compared to the Kharif season.

\subsubsection{Land use Patten}

In the rural areas land is accepted as the most important asset and it is quite natural to expect that all cultivable land is optimally used. But due to acute labor problems farmers are finding it very difficult to carry on agricultural operations and some are forced to lease out their land and some are compelled even to leave them fallow and idle. The details of land use statistics are given in Table-11.

Table-11: Land utilization Pattern

\begin{tabular}{|c|c|c|c|c|}
\hline \multirow{2}{*}{ Year } & Household Category & $\begin{array}{c}\text { Cultivable Total } \\
\text { Area(in Acres) }\end{array}$ & NAS( in Acres) & Idle land ( in Acres) \\
\hline $\mathbf{1}$ & $\mathbf{2}$ & $\mathbf{3}$ & $\mathbf{4}$ & $\mathbf{5}$ \\
\hline \multirow{3}{*}{2002} & Migrants & 199 & $185.14(93.04)$ & $13.86(6.95)$ \\
\cline { 2 - 5 } & Returned Migrants & 126 & $122.22(97.00)$ & $3.78(3.00)$ \\
\cline { 2 - 5 } & Non-Migrants & 649 & $633.61(97.63)$ & $15.39(2.36)$ \\
\cline { 2 - 5 } & All & 974 & $940.97(96.61)$ & $33.03(3.39)$ \\
\hline \multirow{4}{*}{$\mathbf{2 0 0 7}$} & Migrants & 211 & $190.174(90.13)$ & $20.82(9.86)$ \\
\cline { 2 - 5 } & Returned Migrants & 128 & $608.12(95.02)$ & $6.43(5.01)$ \\
\cline { 2 - 5 } & Non-Migrants & 640 & $919.86(93.96)$ & $31.88(4.98)$ \\
\cline { 2 - 5 } & All & 979 & $179(80.26)$ & $59.13(6.03)$ \\
\cline { 2 - 5 } & Returned Migrants & 223 & $114(88.03)$ & $44(19.73)$ \\
\cline { 2 - 5 } & Non-Migrants & 129.5 & $585(92.41)$ & $15.5(11.96)$ \\
\cline { 2 - 5 } & All & 930 & $878(89.36)$ & $45(7.14)$ \\
\hline
\end{tabular}

Source: Primary Survey

Figures in Parentheses indicate percentages to Total

As the table shows, there has been a consistent decline in the amount and percentage of net area sown (NAS) in the study area over the reference period. The share of NAS in cultivable total area has declined from 96.61 per 
cent in 2002 to 93.96 per cent in 2007 and 89.36 per cent in 2012.This suggests that the share of land left fallow has increased from 3.39 per cent in 2002 to 6.03 per cent in 2007 And 10.63 per cent in 2012. A similar trend is observed across the three categories of households. But unsurprisingly the reeducation in the share of area left idle is higher in the case of the migrant households than for others. This indicates that migrant households are more affected by labour problems than others in respect of cultivation.

\section{Summary of Findings and Policy Implications}

The motivation for this paper came from our concern for the crisis in contemporary agriculture arising, among other things, from increasing labour shortage caused by migration, unwillingness of people to work in dust and mud and provision of works under MNREGA; and rising wages resulting from increasing demand for and falling supply of farm labour. The provision of $25 \mathrm{kgs}$ of rice at one rupee price to BPL households has the additional effect of encouraging withdrawal from the labour market. Since farm wages are determined by the demand for and supply of labour, the pervasive perception that wages are increasing because of MNREGA and minimum wage laws has been successfully invalidated. Further, the observed agricultural wage rate being greater than the statutory minimum is proof of the blatant irrelevance of minimum wage laws and higher male wages relative to female wages is suggestive of gross violation of constitutional mandates of gender justice. Moreover, migration of prime age male workers has led to a kind of senilitisation and feminization of agricultural labour.

Our findings reveal a declining trend of labour use and a rising trend of wage cost per unit of cultivated land- a conflicting situation convincingly explained by rising wage rates. Second, wages constitute the single largest component of operational cost of cultivation and charges on account of farm machinery come next indicating that agriculture still continues to be a highly labour-intensive activity and farmers are resorting to increasing mechanization with the help, among others, of remittances to compensate the lost labour. Despite rising wages and reduced labour use, output per acre and per person day of labour has been increased and the unit cost of output has lowered because of mechanization of farm operations and adoption of improved farm practices. Economic motivation and labour and wage problems have been observed to have induced some changes in cropping pattern favouring relatively less labour-intensive non-paddy crops, but despite such improvements paddy still continues to be the giant claimant (73.35 per cent) of cultivated land. Alarmingly, pursuing agriculture has become an increasingly difficult task owing to serious labour-wage problems compelling some farmers to lease out and /or leave some of their cultivable land idle and fallow.

The following policy implications have emerged from our study.

4.1 It is imperative to expedite diversification within agriculture favouring vegetables, groundnut, pulses, floriculture, poultry, dairy and pisciculture which are more profitable, less grueling and considered less derogatory to pursue and better suited to absorb labour supply shocks.

4.2 Promotion of location and small farm size specific technological innovations, gearing up of Krishi Vigyan Kendras and agricultural extension systems, developing female labour friendly farm machinery and training of farmers to encourage adoption of sustainable labour-saving cultivation practices can help to cope with labour scarcity.

4.3 A community approach to agricultural labour under which voluntary groups of farmers pool labour to work on each other's farms through a kind of exchange labour arrangement and buy costly machinery and implements in terms of a custom hiring system to promote farm mechanization can offset reduced labour supply and compensate lost labour to some extent.

4.4 Evolving an integrated production-processing-storage- marketing system of agriculture, encouraging contract farming and developing micro agricultural enterprises will minimize post-harvest losses, provide lucrative gainful and regular employment and can be useful in retaining workers in agriculture.

4.5 Redesigning MNREGA works so as not to coincide with the peak periods in cereal-centric agriculture, an effective and remunerative agricultural price policy, and provision of adequate rural infrastructure can not only help to moderate labour problems but also make agriculture economically rewarding.

4.6 The food security programme, provision of $25 \mathrm{kgs}$ of rice at Re 1/kg to BPL families in particular, is well received in different circles. But it has catapulted the agricultural sector through promotion of the menacing unwillingness-to-work syndrome in the people. It is high time government should evolve some kind of mechanism to integrate the food security benefits with a positive attitude to work among the beneficiaries. The benefits should go to the deserving people against work contribution. 


\section{References}

[1]. Azam, Jean-Paul and Flore Gulbert. (2006), Migrant Remittances and Economic Development in Africa: A Review of Evidence, Journal of African Economies, Vol. 15(2), pp.426-462.

[2]. -------- (2005), Those in the Kayes: The Impact of Remittance on the Recipients in Africa, Revue Economique, Vol.56(6), pp. $1331-1358$.

[3]. Bardhan,P. (1973), Factors Affecting Wage Rates for Agricultural Labour, Economic and Political Weekly, Vol.8, pp. A56-A63.

[4]. - -------- (1977), Rural Employment, Wages and Labour Markets in India: A Survey of Research; Part I,II, and III, Economic and Political Weekly, Vol. 12,pp. A34-A48,1062-1074,1108-1118

[5]. - --------- (1979), Wages and Unemployment in a Poor Agrarian Economy: A Theoretical and Empirical Analysis, Journal of Political Economy, Vol. 87, pp.479-500.

[6]. Brennan, D., Elizabeth Petersen, Nguyen Ngoc Que and David Vanzetti. (2012), Rural-Urban Migration and Vietnamese Agriculture, 56 ${ }^{\text {th }}$ AARES Annual Conference, Fremantle, Western Australia, 7-10 ${ }^{\text {th }}$ February 2012.

[7]. Binswanger, Hans P. and M.R. Rosenzweig. (1986), Behavioral and Material Determinants of Production Relations in Agriculture, The Journal of Development Studies, Vol.32, pp. 503-539.

[8]. Binswanger, H.P. and M.R. Rosenzweig, eds. (1984), Contractual arrangements, employment and wages in rural labor markets in Asia ,Yale University Press, New Haven.

[9]. Clark, J.B. (1899),The Distribution of Wealth: A Theory of Wages, Interest and Profits, 1927 edition, New York: Macmillan.

[10]. de Brauw, A. (2010), Seasonal Migration in Vietnam, ESA Working Paper No. 07-04.

[11]. Funkhouser,E. (1992), Migration from Nicaragua: Some Recent Evidence, World Development, Vol.20(8).pp. 1209-1218.

[12]. Germenji, E. and Swinnen, J. (2004), Impact of Remittances on Household-based Farms in Rural Albania, Paper Presented at the International Conference on New Perspectives on Albanian Migration and Development, Albania.

[13]. Hicks, J.R. (1932a), The Theory of Wages, London: Macmillan.

[14]. --------- (1932b) Marginal Productivity and the Principle of Variation, Economica Vol.12, pp. 79-88.

[15]. ----------(1932c), A Rejoinder, Marginal productivity and the Lausanne School, a reply to Henry Schultz, Economica, Vol.12, pp. 297-300.

[16]. Itzigsohn, Jose. (1995), Migrant Remittances, Labor Markets, and Household Strategies: A Comparative Analysis of Low-Income Household Strategies in the Caribbean Basin, Social Forces, Vol.74(2), pp. 633-55.

[17]. Leibenstein,H.(1957), The Theory of Underemployment in Backward Economies, Journal of Political Economy, Vol.65( 2), pp. 91103.

[18]. Lewis,W.A. (1954), Economic Development with Unlimited Supply of Labour, The Manchester School,Vol.22(2),pp. 139-191.

[19]. Lipton, Michael. (1980), Migration from the Rural Areas of Poor Countries: The Impact on Rural Productivity and Income Distribution, World Development, Vol. 8(1), pp. 1-24.

[20]. Lucas,R.E.B. (1987), Emigration to South Africa's Mines, The American Economic Review, Vol. 77(3), pp.313-30.

[21]. Majumdar,D. (1959), Marginal Productivity Theory of Wages and Disguised Unemployment, Review of Economic Studies, Vol. 26.pp.190-197.

[22]. Mc Carthy, N.Carletto,G.Davis and I. Maltsglou. (2006), Assessing the Impact of Massive Out-Migration on Agriculture,ESA Working Paper, No.06-14, FAO, Rome

[23]. Miluka J., Gero Carletto, Benjamin Davis, and Alberto Zezza. (2010), The Vanishing Farms? The Impact of International Migration on Albanian Family Farming, Journal of Development Studies, Vol. 46(1), pp.140-161.

[24]. Mirrlees, J.A.(1975), A Pure theory of Underdeveloped Economies in Reynolds, L.G. (ed), Agriculture in Development Theory, Yale University Press.

[25]. Ofuoku and Chukwuji. (2012), The Impact of Rural-Urban Migration on Plantation Agriculture in Nigeria Delta Region, Nigeria, Journal of Rural Social Sciences, Vol. 27(1), pp.137-51.

[26]. Palmer, I. (1985), The Impact of Male Out-Migration on Women in Farming, West Hartford, CT: Kumarian Press.

[27]. Parganiha, O. P., M.L.Sharma, P.M.Praye, and V.K Soni. (2009), Migration effect of Agricultural Labourers on Agricultural Activities. Indian Research Journal of Extension Education, Vol. 9 ( 3), pp. 95-98.

[28]. Prabakar, C., K. Sita Devi and S. Selvam. (2011), Labour Scarcity-Its immensity and Impact on Agriculture, Agricultural Economics Research Review, Vol.24 (conference number), pp. 373-380.

[29]. Ranis, G., and J.C. Fei. (1964), Development of the Labor Surplus Economy: Theory and Policy, Homewood, Ill, R.D. Irwin.

[30]. Rodgers, G.B.(1975), Nutritionally Based Wage Determination in Low Income Labour Market, Oxford Economic Papers.

[31]. Rodriguez, E., and E.R. Tiongson . (2001), Temporary migration overseas and household labor supply: evidence from urban Philippines, International Migration Review, Vol.35 (3), pp. 709-725.

[32]. Rozelle, S., J.Taylor, and A. de Brauw, A. (1999), Migration, Remittances and Agricultural Productivity in China. American Economic Review, 89(2), pp. 287-291.

[33]. Sraffa, P. (1960), Production of Commodities by Means of Commodities: Prelude to a Critique of Economic Theory, Cambridge University Press, Cambridge.

[34]. Stiglitz, J. E.(1976), The Efficiency Wage Hypothesis, Surplus Labour and Distribution of Income in LDCs, Oxford Economic Papers.Vol.28(2),pp. 185-207.

[35]. Sukhatme, P. (1978), Assessment of Adequacy of diets at different income levels, Economic and Political Weekly, Special Number, pp.1373-1384.

[36]. Vaidyanathan, A. (1980), Unemployment and Wages in an Agrarian Economy, Working Paper No.120, Centre for Development Studies, Trivandrum. 